\title{
Leadership \& Professional Development: Lessons Learned From the Other Side of the Stethoscope (and Endotracheal Tube)
}

\author{
Scott Kaatz, DO, MSc
}

Division of Hospital Medicine, Henry Ford Hospital, Detroit, Michigan.

"One of the essential qualities of the clinician is interest in humanity, for the secret of the care of the patient is in caring for the patient."

_Francis Peabody, 9 years after the pandemic of 1918

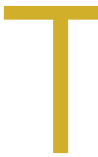

wo weeks after rounding on a coronavirus disease 2019 (COVID-19) unit at the start of the surge in Detroit, Michigan, I got infected. Simultaneously, my father was also fighting COVID-19, and we were mechanically ventilated at the same time. He was admitted a week before I was and, devastatingly, died about a week after I was discharged. I have three major takeaways from my experience that now inform how I practice.

\section{CARE TEAMS}

I have always appreciated what a valuable member of the team nurses are, but to experience the caring reflected in their smiling eyes, magnified by a face shield, is an indelible image-compassion with passion. They risked their lives to save my life, but I am also grateful to the maintenance person who risked their life to fix the toilet in my room in the intensive care unit, the transportation aides and radiology techs who risked their lives so I could get a computed tomography scan, environmental services personnel, and too many to mention who put on personal protective equipment to care for my father and me. Lesson \#1: Repeatedly thank everyone caring for patients. Now, when I am on rounds, I try to remember to say thank you to each member each day.

\section{LOVED ONES' COMMUNICATION}

As my dyspnea worsened, a big concern (besides the "I might die" thing) was communicating with family. It turns out that my

Corresponding Author: Scott Kaatz, DO, MSC; Email: SKAATZ1@hfhs.org; Telephone: 248-390-2318.

Received: October 30, 2020; Accepted: November 11, 2020

(c) 2021 Society of Hospital Medicine DOI 10.12788/jhm.3571 short cell phone cord could only stretch to just under my pillow, and reaching that far was exhausting when on high-flow oxygen. Nursing helped me to video chat with my family as we said potential goodbyes just prior to intubation and let me use their bagged personal cell phones when I woke up. Meanwhile, my siblings took over the calls from Dad's team, and I was amazed at how much they had learned about ventilator settings while I was sleeping and how much the clinical team knew about my family. Although Dad's delirium never allowed meaningful conversation or eye contact with us, every day the nurses would facilitate video chatting (again, with their phones) so we could give words of love and encouragement. Lesson \#2: I have redoubled my efforts to keep families in the loop and carry a phone/tablet charger with a long cord to lend/give my patients, if needed.

\section{FAITH}

While I was prone, paralyzed, and sedated, I had no awareness of my medical treatments, thanks to the skill of my caregivers. It is impossible to express my gratitude to those who sent good wishes that virtually always included the phrase, "We were praying for you"; I hope my prayers got through to Dad. In their call to more fully address religion and spirituality in medicine, Collier et al ${ }^{1}$ remind us that approximately $90 \%$ of Americans have faith, and more than half state that religion is very important to them, yet I, like many, do not routinely incorporate this aspect into my discussions with patients or the care team. Lesson \#3: Begin to more actively facilitate my patients' spirituality into the team's caring process.

Disclosure: The author has nothing to disclose.

\section{Reference}

1. Collier KM, James CA, Saint S, Howell JD. Is it time to more fully address teaching religion and spirituality in medicine [editorial]? Ann Intern Med. 2020;172(12):817-818. https://doi.org/10.7326/M20-0446 